\title{
RUSSIAN ENERGY SECTOR IN THE FACE OF SANCTIONS
}

\begin{abstract}
As a result of the annexation of Crimea and the Russian aggression in Ukraine in 2014, the United States as well as other states and international organizations decided to impose economic sanctions against the Russian Federation. The sanctions were mainly directed against the energy and banking sectors. The following article presents the condition of the Russian energy sector after 2014 with regard to the consequences of the Western sanctions.
\end{abstract}

\section{Key words}

Russian Federation, sanctions, energy sector, natural gas, crude oil

Since Vladimir Putin seized power in Russia, the state has been frequently referred to as petrol state. Such subject is characterized mainly by its economy (GDP) based on income from extraction of energy resources (crude oil, natural gas and coal). In the case of Russia, these resources have been used also as instruments of internal and foreign policy ${ }^{1}$. The control over companies from the energy sector has brought substantial financial resources and could be used

1 An example of adopting resource policy was the situation from December 2005, when Russia cut off its energy supply to Ukraine in order to force the state to pay higher price for gas. 
to influence other states. Undoubtedly, the downside of such system is the state's financial dependence on price fluctuations in global resource markets (Smith, 2006).

In response to the 2014 aggression in Ukraine, the European Union (the EU), the United States (the US) and other countries and international organizations imposed on Russia a package of economic sanctions. One of the major sectors affected by the sanctions has been the energy sector. The aim of this article is to analyze the condition of Russian energy sector after 2014 with regard to the effects it experienced in the face of the Western sanctions. The main research problem is to answer the question: to what extent has Russian energy sector coped with the sanctions and by what means. The research method applied is mainly content analysis. The research is based on Polish and English sources due to their higher credibility.

\section{Russian energy sector - a brief profile}

The energy sector is a conglomerate of many branches. It includes production of electrical energy ${ }^{2}$, coal industry, and production of crude oil and natural gas. In the Russian Federation it is the state that plays the main role in managing and developing the energy sector. One of the factors shaping the energy sector in Russia is its monopolistic structure. Companies from the energy sector are tightly linked with representatives of the power elites. Putin's closest associates keep control over the entities operating in the energy market. Thus export of resources is an important instrument of the current domestic and foreign policy (Menkiszak, 2014).

In 2013 the most important company in the gas sector was Gazprom (managed by a Putin's close associate Alexey Miller) (Zavalny et al., 2015). It should be noted that Russia had the biggest share in the world production of natural gas: Gazprom controlled around 58\% of all prospected resources of natural gas (Wasilewski, 2005). In 2012 European states (together with Turkey) were definitely the most important market for Gazprom (98.5\% of Russian export of gas, of which $27.5 \%$ went to the member states of the Commonwealth of Independent States (the CIS); $57 \%$ to the EU member states, and $14 \%$ to other European countries (Czerniewicz, 2015).

2 The production of electrical energy in Russia is based mainly on gas (46\%), coal (18\%), hydropower (18\%) and nuclear power (17\%). 
A fuel of strategic importance for the Russian Federation is crude oil, which occupies the key position in Russian export ${ }^{3}$. Its deposits can be found in 40 Russian administrative regions. The company responsible for management of national oil pipelines is Transneft. The companies which extract crude oil are Rosneft, Lukoil, Gazprom, Bashneft, Surgutneftegaz, Transneft and Tatneft. Thanks to the income from export of crude oil the Russian Federation maintained a significant geopolitical position. However, the state became strongly dependent on this export, and thus other sources of income were neglected (Kończuk, 2012). In 2013 Russia was the second exporter of crude oil in the world with a share of $13.2 \%$ (after Saudi Arabia). The main importers were the EU member states and Balkan States (60\% of total sales), the CIS (21\%), Asia (12\%), North and South America (6\%), Africa (0.7\%), Australia (0.3\%) (Kończuk, 2012).

Until 2013 the export of coal was also growing. On the territory of the Russian Federation there is $1 / 3$ of the world's coal deposits (of which a fifth is documented) and $70 \%$ of lignite deposits. In 2010 the prices of coal began to increase, which caused almost 10\% increase in Russian production until 2012. Putin approved a long-term plan for development of coal industry in Russia. The program assumed that by 2030 the extraction of coal would have increased to 430 million. The two main Russian coal producers are Rosugol and Donugol. Over two-thirds of the coal produced in Russia is used in the country (Safirowa, 2015). The main importers of Russian coal in 2013 were China, the United Kingdom, South Korea and Japan (Russian Energy - 2014, 2015). In 2013 Russia was the leader in coal exports, but it had to struggle with strong competition (China, the USA, India, Australia, Indonesia) (Savchina, Savchina, Asinovich, Kosyakov \& Bobkov, 2017).

The following table presents the value of production and export of individual energy resources in the years 2008-2013. It should be noted that in that period there was an increase in production of energy resources, except the negative trend during economic crises (2009 and 2013). One of the main reasons for the slowdown in 2013 were poor results of growth in global economy, including the biggest recipients of Russian fuels. Another reason was the monetary policy that influenced maintaining high interest rates on loans, which with the simultaneous strengthening of the ruble resulted in a decline in the competitiveness of Russian enterprises and hindered their economic activity (Fischer, 2012).

3 For example, in 2010 the income to the state's budget from export of crude oil and related products reached $44 \%$. 
Table 1. Production and extraction of energy resources in Russia in 2008-2013

\begin{tabular}{|l|l|c|c|c|c|c|c|}
\hline \multicolumn{2}{|c|}{} & $\mathbf{2 0 0 8}$ & $\mathbf{2 0 0 9}$ & $\mathbf{2 0 1 0}$ & $\mathbf{2 0 1 1}$ & $\mathbf{2 0 1 2}$ & $\mathbf{2 0 1 3}$ \\
\hline \multirow{2}{*}{ Crude oil } & $\begin{array}{l}\text { Production (in millions of barrels } \\
\text { per day) }\end{array}$ & 9.85 & 10.03 & 10.26 & 10.38 & 10.59 & 10.73 \\
\cline { 2 - 8 } & $\begin{array}{l}\text { Export (in millions of barrels } \\
\text { per day) }\end{array}$ & 5.08 & 4.96 & 4.97 & 4.78 & 7.75 & 4.68 \\
\hline \multirow{2}{*}{$\begin{array}{l}\text { Natural } \\
\text { gas }\end{array}$} & Production (bn m $)^{3}$ & 621 & 546 & 610 & 628 & 656 & 627 \\
\cline { 2 - 8 } & Export (bn m $\left.{ }^{3}\right)$ & 237 & 211 & 228 & 231 & 203 & 218 \\
\hline Coal & Production (in millions of tonnes) & 326 & 298 & 323 & 336 & 354 & 352 \\
\cline { 2 - 9 } & Export (in millions of tonnes) & 108 & 116 & 127 & 122 & 145 & 156 \\
\hline \multirow{2}{*}{ Economic growth } & $\mathbf{5 . 2 \%}$ & $\mathbf{- 7 . 8 \%}$ & $\mathbf{4 . 5 \%}$ & $\mathbf{5 . 0 \%}$ & $\mathbf{3 . 7 \%}$ & $\mathbf{1 8 \%}$ \\
\hline
\end{tabular}

Source: own work based on: Global economy. https://www.theglobaleconomy.com/Russia/ and CEIC data, https://www.ceicdata.com/en/indicator/russia/natural-gas-exports.

\section{Energy sector - barriers to development}

Export of natural gas and crude oil together with derived products constitutes a half of the revenue to the Russian budget. Representatives of the Russian authorities for many years emphasized the need for diversification and increase in non-fuel export. The steps taken in this regard brought no measureable effects. The situation was worsened by the fact that with imposing the first sanctions against the Russian Federation in 2014, political stability of the state was strongly conditioned by the global prices on fuel markets. Besides that fact, the energy sector had to face numerous other challenges (Menkiszak, 2014).

The problems were related in majority to the gas sector. A serious threat for the stability of the Russian model of development of traditional gas was the growing role of LNG (liquefied natural gas) and the shale gas revolution. For many years Gazprom denied that it could constitutes a threat for the company's interest. While on the global gas market new condensing and regasification terminals were being built and the race for the leading positions on the LNG market continued, Russia was completing its large and expensive infrastructural projects (Nord Stream 2, Turkish Stream or the Power of Siberia, South Stream). 
The first Russian terminal for LNG production - Sakhalin 2 (financed mainly by foreign partners) was not opened until 2009 (Rutkowski, 2018). Since 2012, the LNG export has been liberalized, granting the right to other companies that meet specific criteria. Efforts were also made to grow in strength on Asian markets through LNG. On January 102013 Gazprom and Novatek OAO (the largest independent gas producer in Russia) signed an agreement to create a joint venture tasked with the production of liquefied gas on the Yamal Peninsula.

The main reason for delays in this field was the stance of Gazprom, which strove to maintain the export monopoly in the gas sector. Gazprom wanted to implement LNG projects in cooperation with partners, passing some part of the costs on to them (Kardaś, 2013). It should be noted that another problem of the gas sector was the fact that Gazprom had to face growing competition from domestic rivals who demanded abolition of its monopoly on gas sales abroad and making Gazprom transmission infrastructure available to them (Czerniewicz, 2015).

The EU energy policy, which aimed at creating a common market, liberalizing it and diversifying energy sources, was a challenge for the energy sector of the Russian Federation even before imposing economic sanctions against this state. About $30 \%$ of gas imported by the EU came from Russia, so it was impossible to eliminate Russian gas from the supplies. The policy of price diversification and unification would be against the interest of Gazprom, which until then had individualized the prices of fuel supplies. Diversification of supplies would reduce the dependence of European countries on Russian gas, which would mean that the energy issue would not be such an effective tool in foreign policy (Tomaszewski, 2018). A possible strategy could have been a change of export directions (towards the Asian market), but until 2014 there was no proper legal basis for it.

Another barrier to the development of the energy sector was the problem with infrastructure. Until 2014, the transmission system inside Russia was being expanded, raising the level of gasification of the country, but the achieved rates were much lower than assumed. Moreover, the existing transmission infrastructure was breaking apart due to its age and required much larger investments than those previously made by Gazprom (Kardaś, 2017). In the oil sector, Russian refineries were technologically obsolete and had low levels of processing efficiency. Foreign expansion proved to be a cheaper way to modernize the sector. This led to the takeover of relatively modern refineries in Belarus and purchasing plants in Germany and Italy (Menkiszak, 2014). What is more, Russian resources of available fuels, particularly crude oil, are decreasing. The level of deposits depletion amounts to $55 \%$. 
Russian problems with the energy sector resulted mainly from the fact that a comprehensive systemic reform of the energy sector was impossible / an impossible task. What remained the most problematic issues were price liberalization, mechanism for setting transmission tariffs, taxation system of the gas sector, and restructurisation of Gazprom as well as putting further limits on its export monopoly (Kardaś, 2017).

\section{Sanctions in energy sector}

In response to the annexation of Crimea and the Russian intervention in the territory of Eastern Ukraine, a number of sanctions were imposed against the Russian Federation. They mainly covered the banking, energy and military sectors as well as technological cooperation. The imposed sanctions were of three types: a ban on providing oil and gas exploration services, a ban on giving loans to Russian oil companies and state-owned banks, and travel restrictions put on influential Russian citizens. The first round of sanctions was introduced in February and March 2014. The European Union imposed economic sanctions on 17 March 2014 and has been successively prolonging them since then. The restrictions are related to reducing access to EU markets. The second round of sanctions was introduced in April of the same year and concerned travel restrictions on people close to President Putin. The third round of sanctions was initiated by the United States on 17 July 2014. The United States expanded the ban on transactions to two Russian energy companies (Rosneft and Novatek) and two banks (Gazprombank and Vnesheconombank) (Smith, 2016). The EU joined on 31 July 2014 by the following actions: introducing embargo on weapons and dual-use goods and technologies for military purposes; putting export controls on oil industry equipment; and limiting emissions of and trade in certain bonds, shares or similar financial instruments. On 12 September 2014, the United States imposed sanctions against the largest Russian bank (Sberbank), the main arms producer (Rostec) and companies from the energy sector - Gazprom, Gazprom Neft, Lukoil and Surgutneftegas. The aim of the sanctions imposed against energy companies was to ban cooperation in the field of technology and services. Other states, such as Canada, Australia, Norway and Japan, also imposed sanctions (Gutterman \& Grojec, 2018).

In August 2017, the US introduced new sanctions against Russia. They were concentrated mainly on tightening previous restrictions and imposing them against entities that supported or invested in the Russian Nord Stream 2 pipeline 
from Russia via the Baltic Sea to Germany as this project was not suspended despite the sanctions. Germany is at the stage of transition to a new technological cycle. Taking into account the closure of German nuclear power plants, their industrial, energy-intensive economy needs cheap Russian gas (Daiss, 2018).

Undoubtedly, the sanctions led to an increase in capital outflow and reduction in the inflow of foreign investments to Russia. According to the Central Bank of the Russian Federation, from 2014 to March 2018, the outflow of capital from Russia was 266 bn USD. The sanctions hit the stability of the Russian currency. However, it is not known what effect the low oil prices had on the value of ruble (in the second half of 2014 and in 2015, prices of crude oil fell from 115 USD to approximately 30 USD), and to what extent this value was influenced by the sanctions (Kost, 2018).

Representatives of the Russian authorities approached the sanctions in a multi-faceted manner. This was to alleviate their negative impact, particularly in the energy sector. It was decided to limit the import of foreign goods and reduce costs in the domestic economy, especially in the purchase of equipment and services for the development of the energy sector. Other important elements of the anti-crisis policy were based on constant efforts to increase export of natural gas to Europe, China and other parts of Asia, and on further efforts to reduce competition in Europe. The latter was visible mainly in the activities aimed at blocking the export of Turkmen gas to Europe (or through the Caspian Sea to connect with Azerbaijani gas in the Southern Gas Corridor or through Russia and Ukraine). The competition with Turkmenistan through building TurkStream and Nord Stream 2 was a priority for Russia (Chang, 2017).

At the same time, the authorities let the value of ruble fall in order to encourage import and lower the costs of domestic supplies. In the energy sector, domestic suppliers of equipment and services were able to substitute imported goods and services at a lower cost. Foreign contractors became obligated to accept ruble as the transfer currency, which lowered the costs for Russian companies. The Russian federation still supported the energy sector through lowering taxes on oil production. As a result, Russia was able to maintain its financial reserves from 2015, when there was a global increase in the price of energy resources (Coote, 2018). 


\section{The energy sector at the time of sanctions}

The sanctions had a significant influence on Russian economy. However, in the short term (several years') perspective they did not harm the energy sector. From the financial point of view, Russia suffered mostly in the first year of the sanctions as the companies were suddenly faced with debts denominated in dollars and euros. Simultaneously, the prices of goods fell, causing huge financial losses. In 2015 the prices of energy and resources stabilized. Russian government gradually resumed investments, which were used by the energy sector. There were also certain foreign investments, particularly from European companies. After the sanctions were imposed in 2014, German investments were suspended or canceled, but in 2016 Germany was in the second place (after China) with regard to the amount of capital invested in Russia (Coote, 2018).

Companies from the energy sector, with the support of the state, coped well with sanctions. As Table 2 demonstrates, after the collapse of production and export in 2013-2014, a gradual increase in the extraction and sale of energy resources has been recorded. The introduced financial sanctions had marginal effects on Russian crude oil trade. Only Japanese companies in August 2014 suspended their participation in tenders. The sanctions also influenced the fact that the Italian refinery Saras abandoned its plans to create with Rosneft a joint venture which would trade in oil and oil products. During the crisis, the key players in the energy sector decided on modifications in the investment budget (e.g. Rosneft in 2015 announced a reduction in investment spending by as much as $30 \%$; Novatek reduced its budget for the year 2015 by 21\%) (Domańska \& Kardaś, 2016).

While in the current perspective economic sanctions did not bring irreversible losses to the energy sector, their effects may prove to be very severe in the long-term and medium-term perspective. Western sanctions do not threaten the mining sector of Russia, but prevent it from implementing ambitious development plans. In the face of the financial crisis, Russian companies limited the investment fund and R\&D. The negligence of the LNG sector development has been of particular importance. Already in 2012 there was a widespread opinion that Russia had slept through the gas revolution. After the sanctions were introduced, the technology gap became even wider. LNG constitutes around $2.4 \%$ of Russian production and just over $7 \%$ of the export of natural gas, while for the global market it is respectively over $15 \%$ and $35 \%$ of export. What may be an example here was the project on production of liquefied gas - Yamal-LNG, 
implemented in cooperation with China and France. The main obstacle turned out to be the sanctions against the Russian banks that were to participate in financing the project. This caused delays in the project. Yamal-LNG was launched only in December 2017 (Zawadzki, 2018). The financial sanctions have also resulted in Gazprom's problems with finding a partner for the construction of LNG liquefaction plants in the Baltic Sea. Also Rosneft's plans remain unrealized. The largest Russian oil company, intensely lobbying for being granted the right to export gas in liquefied form, did not make investment decisions with regard to its plans for building an export terminal in the Far East (the so-called Far East LNG) and Pechora LNG (Nenets Autonomous Okrug) (Kardas, 2018).

Table 1. Production and extraction of energy resources in Russia in 2014-2017

\begin{tabular}{|l|l|c|c|c|c|}
\hline \multicolumn{2}{|c|}{} & $\mathbf{2 0 1 4}$ & $\mathbf{2 0 1 5}$ & $\mathbf{2 0 1 6}$ & $\mathbf{2 0 1 7}$ \\
\hline \multirow{2}{*}{ Crude oil } & Production (in millions of barrels per day) & 10.8 & 11.01 & 11.2 & 11.01 \\
\cline { 2 - 6 } & Export (in millions of barrels per day) & 4.4 & 4.8 & 5.0 & 5.0 \\
\hline \multirow{2}{*}{ Natural gas } & Production (bn m ${ }^{3}$ ) & 601 & 594 & 599 & 646 \\
\cline { 2 - 6 } & Export (bn $\left.\mathrm{m}^{3}\right)$ & 193 & 197 & 208 & 212 \\
\hline \multirow{2}{*}{ Coal } & Production (in millions of tonnes) & 358 & 355 & 351 & 407 \\
\cline { 2 - 6 } & Export (in millions of tonnes) & 167 & 166 & 181 & 185 \\
\hline \multirow{2}{*}{ Economic growth } & $\mathbf{0 . 7}$ & $\mathbf{- 2 . 5}$ & $\mathbf{- 0 . 2}$ & $\mathbf{1 . 5}$ \\
\hline
\end{tabular}

Source: own work based on: Global economy. https://www.theglobaleconomy.com/Russia/ and CEIC data, https://www.ceicdata.com/en/indicator/russia/natural-gas-exports.

It is also worth noting that since 2014 Russians have been gradually decreasing their dependence on Western technologies, financing and cooperation in the oil and gas sector. The sanctions have slowed down the development of a number of oil projects, but they did not block the increase in oil extraction: July 2018 brought a bumper result of 11.2 million barrels per day. Rosneft, which extracts $40 \%$ of Russian crude oil, has recently tested its own technology of hydraulic fracturing. However, the Western restrictions threaten new projects related to LNG, crude oil processing and the petroleum industry, where American and European technologies are widely used (Sankcje, ropa i gaz, 2018). 
However, the sanctions contributed to the problems of Gazprom, which in 2014 recorded the lowest level of gas production in its history. This was due to the decline in export, lower demand resulting from the mild winter, economic slowdown in Europe and large amounts of fuels coming from other sources. Losses were also brought by the Ukrainian market, which in previous years absorbed even over 30 billion cubic meters of gas. The losses for Gazprom were caused by the US sanctions against the Yuzhno-Kirinskoe field (the Sea of Okhotsk), which belongs to the group. They were banned from exporting and reexporting American equipment and technologies necessary to mine the deposit. Gazprom's problems result also from the growing competition in the gas sector, that is, the strengthening of Novatek and Rosneft on the market. Already in 2013 there were changes in gas exports. Rosneft and Novatek received licenses to sell LNG abroad. (Czerniwicz, 2015).

In the face of sanctions, Russia began searching for new partners. However, the main recipients of Russian crude oil were still European countries (particularly the Netherlands, Germany, Poland and Belarus). In 2015 Russia became the main supplier of oil to China, thus taking over the dominance in this market from Saudi Arabia and Angola. In the first half of 2018, the export of crude oil to China exceeded the other directions (Paraskova, 2018). The main recipients of Russian gas were Germany, Turkey, Italy, Great Britain, Belarus and Kazakhstan (Neftyanaya otrast, 2017). The most important coal importers in 2018 were Japan, China, South Korea, Turkey, Great Britain, Ukraine, Poland and Latvia (Grachev, 2018).

There is still a risk that in Europe soon the demand for gas will fall and/or the continent will turn to LNG. First of all, even now there is a visible tendency to move away from long-term contracts - traditionally more beneficial for the supplier. There are also certain visible tensions between the European Commission and Gazprom (accusations of monopolistic practices, withdrawal from the South Stream project). The problem of the gas sector lies in the fact that Russia has many troubles with diversification of recipients and depends on trade with Europe as the development of the Asian direction requires financial investment in infrastructure. 


\section{Conclusions}

Some experts say that the sanctions had no negative results for the Russian energy sector, and even stimulated domestic production and technological development in Russia. Others believe that the sanctions will soon have disastrous consequences due to the sector's strong dependence on foreign capital and technologies. The following figures present Russian production and export of individual energy resources in 2008-2017.

Figure 1. Production and export of natural gas from the Russian Federation in 2008-2017

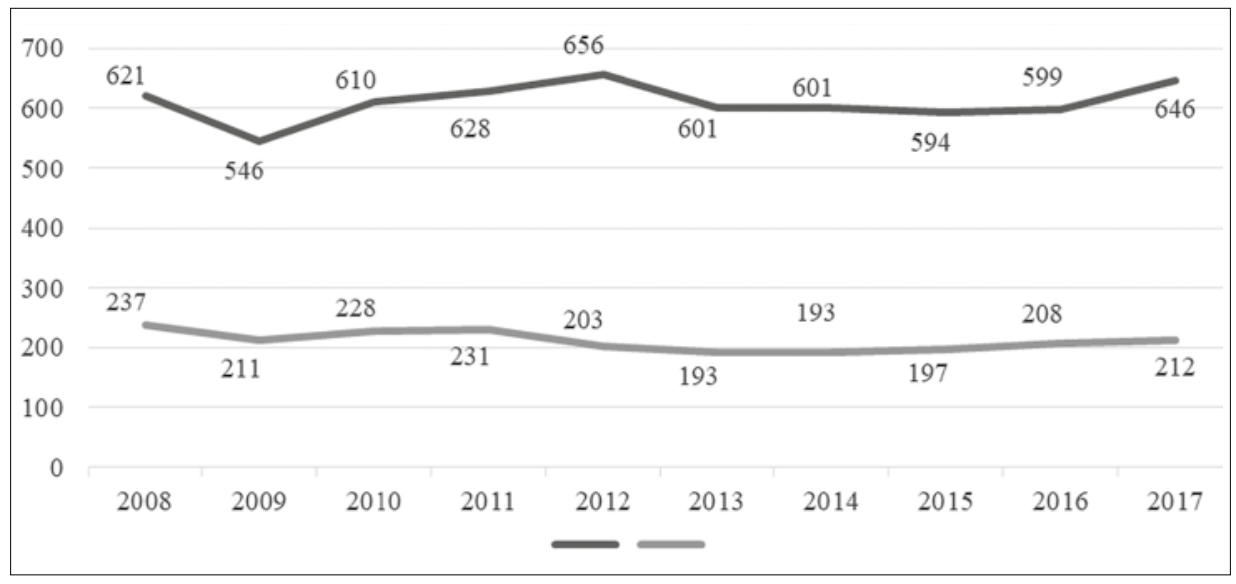

Figure 2. Production and export of crude oil from the Russian Federation in 2008-2017

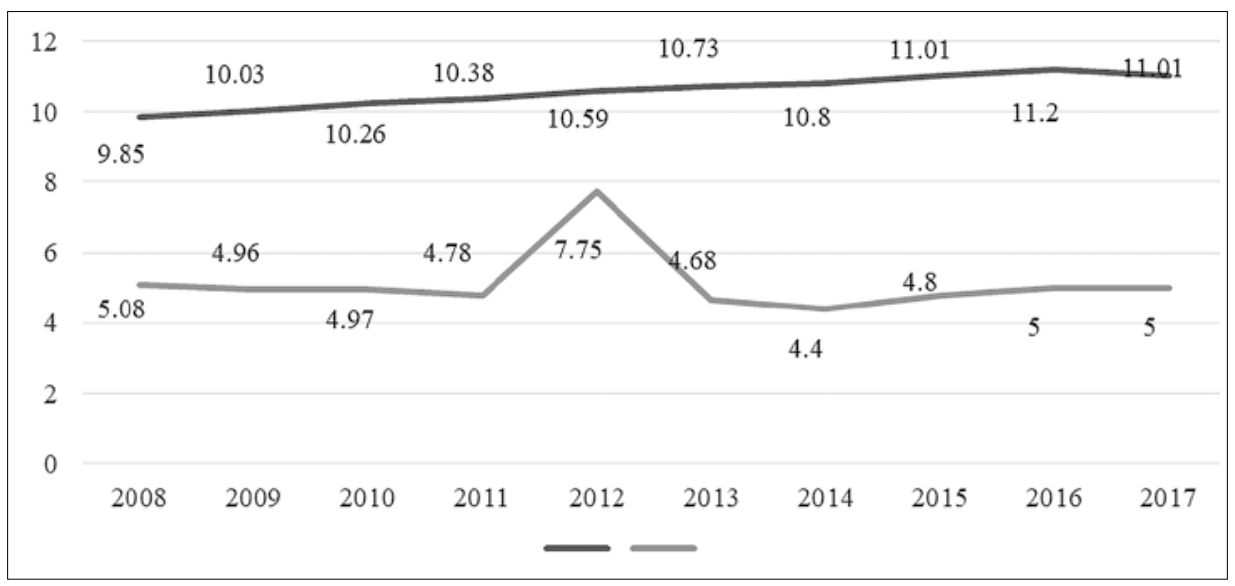


Figure 3. Production and export of coal from the Russian Federation in 2008-2017

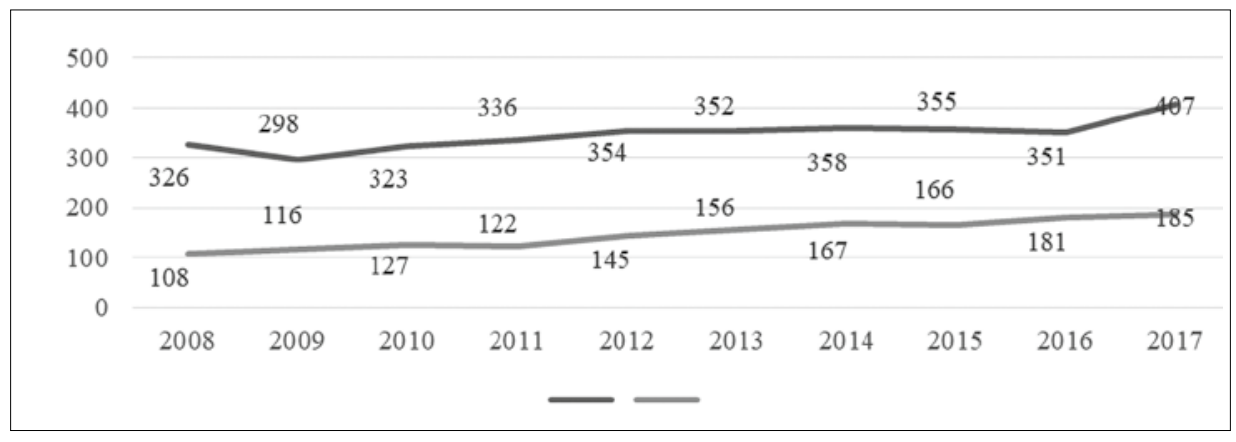

It is difficult not to agree with the opinion that in the short-term perspective Russia effectively dealt with the sanctions against the energy sector. This results mainly from the fact that too many countries depend on the fuel supplies from the Russian Federation. Russian authorities took numerous actions aimed at minimizing the effects of the sanctions. Those actions turned out to be effective as the production and export of Russian fuels came back to the level from before the sanctions. The problems of the gas sector result from the problems of Gazprom, which has to face internal competition and negative trends. Undoubtedly, in the middle- and long-term perspective, the export of Russian gas to Europe will fall since the EU is trying to increase the diversity of its fuel suppliers. Another threat may be LNG. The Asian market in its present shape will not constitute an alternative for the European market.

A true blow to the Russian oil sector would be if Western countries introduced measures similar to those against Iran: a ban on buying Russian oil. However, this is not a realistic scenario since Russia provides over $11 \%$ of global extraction of crude oil. Banning Russian oil would mean a sharp increase in the prices of oil and fuels in the world. 


\section{REFERENCES}

Sankcje, ropa i gaz. Słabości i atuty Rosji. (2018). Retrieved from https://warsawinstitute. org/pl/sankcje-ropa-gaz-slabosci-atuty-rosji/

Chang, F. K. (2017). Effectiveness of Economic Sanctions on Russia's Economy. Retrieved from https://www.fpri.org/2017/06/effectiveness-economic-sanctions-russias-economy/

Coote, B. (2018). Impact of sanctions on Russia's energy sector. Retrieved from https:// webcache.googleusercontent.com/search?q=cache:9yQrwk0dWoEJ:https://www. atlanticcouncil.org/publications/reports/impact-of-sanctions-on-russia-s-energy-se $\mathrm{ctor}+\& \mathrm{~cd}=1 \& \mathrm{hl}=\mathrm{pl} \& \mathrm{ct}=\mathrm{clnk} \& \mathrm{gl}=\mathrm{pl} \& \mathrm{client}=$ firefox $-\mathrm{b}$

Czerniewicz, K. (2015). Sektor gazowy Rosji. Gazprom w defensywie. Retrieved from https://oaspl.org/2015/08/31/sektor-gazowy-rosji-gazprom-w-defensywie/

Daiss, T. (2018). Nord Stream 2 Could Still Be Derailed By U.S. Sanctions. Retrieved from https://oilprice.com/Energy/Natural-Gas/Nord-Stream-2-Could-Still-Be-DerailedBy-US-Sanctions.html

Dąbrowski, S. (2015). LNG w Rosji: Olbrzym jest karłem. Retrieved from https://webcache.googleusercontent.com/search?q=cache:lU7yyFB4DhUJ:https://fundacjagloballab.files.wordpress.com/2015/09/lng-w-rosji_olbrzym-jest-karc582em1.pdf+\&cd $=2 \& \mathrm{hl}=\mathrm{pl} \& \mathrm{ct}=\mathrm{clnk} \& \mathrm{gl}=\mathrm{pl} \& \mathrm{client}=$ firefox $-\mathrm{b}$

Domańska, M., \& Kardaś, S. (2016). Konsekwencje zachodnich sankcji finansowych dla gospodarki Rosji. Retrieved from https://www.osw.waw.pl/pl/publikacje/ komentarze-osw/2016-03-24/konsekwencje-zachodnich-sankcji-finansowych-dlagospodarki

Fischer, E. (2012). Stagnacja rosyjskiej gospodarki. Retrieved from https://www.osw. waw.pl/pl/publikacje/analizy/2013-05-22/stagnacja-rosyjskiej-gospodarki

Gutterman, I., \& Grojec, W. (2018). A Timeline Of All Russia-Related Sanctions. Retrieved from https://www.rferl.org/a/russia-sanctions-timeline/29477179.html

Grachev, S. (2018). Should we expect a crisis in the Russian coal industry? Retrieved from http://www.mining.com/web/expect-crisis-russian-coal-industry/.

Kardaś, S. (2013). Rosja aktywizuje się w sektorze LNG. Retrieved from https://www. osw.waw.pl/pl/publikacje/analizy/2013-01-16/rosja-aktywizuje-sie-w-sektorze-lng

Kardaś, S. (2017). Na rozdrożu. Aktualne problemy rosyjskiego sektora gazowego. Retrieved from https://www.osw.waw.pl/pl/publikacje/prace-osw/2017-03-27/na-rozdrozu

Kardaś, S. (2018). OSW: Ekspansja na koszt państwa - Novatek motorem rosyjskiego sektora LNG. Retrieved from http://biznesalert.pl/osw-ekspansja-na-koszt-panstwanovatek-motorem-rosyjskiego-sektora-lng/

Kończuk, W. (2012). Najlepszy sojusznik Rosji. Kondycja i perspektywy rosyjskiego sektora naftowego. Retrieved from https://www.osw.waw.pl/pl/publikacje/praceosw/2012-04-15/najlepszy-sojusznik-rosji-kondycja-i-perspektywy-rosyjskiego 
Kost, P. (2018). Zjeść ciastko i mieć Krym, czyli o niedziałających sankcjach na Rosję [ANALIZA]. Retrieved from https://www.energetyka24.com/zjesc-ciastko-i-mieckrym-czyli-o-niedzialajacych-sankcjach-na-rosje-analiza

Menkiszak, M. (2014). Geopolityka energetyczna Rosji. Retrieved from https://cse.ibngr. pl/geopolityka-energetyczna-rosji/

Paraskova, T. (2018). China's Russian Oil Imports Hit Record High, Iran Intake Slumps. Retrieved from https://oilprice.com/Latest-Energy-News/World-News/ Chinas-Russian-Oil-Imports-Hit-Record-High-Iran-Intake-Slumps.html

Russian Energy - 2014. (2015). Retrieved from ac.gov.ru/files/publication/a/6490.pdf

Rutkowski, J. (2018). Rosja przegapiła surowcową rewolucję. Kreml nie istnieje na światowym rynku LNG. Retrieved from https://forsal.pl/artykuly/1386621,rosjaprzegapila-surowcowa-rewolucje-kreml-nie-istnieje-na-swiatowym-rynku-lng. html

Safirowa, I. (2015). The Mineral Industry of Russia. US Geological Survey Minerals Yearbook, $1-22$.

Smith, J. (2016). Ukraine-/Russia-Related Sanctions Update and Overview: U.S. and EU Reaffirm Sanctions. Retrieved from http://www.stewartlaw.com/article/ViewArticle/1078

Smith, K. (2006). Current implications of Russian energy policies. Retrieved from http://csis-prod.s3.amazonaws.com/s3fs-public/legacy_files/files/media/csis/ pubs/060112_russian_energy_policies.pdf

Savchina, O. V., Asinovich, A. V., Kosyakov M. A., \& Bobkov A. L. (2017). Energy Sector of the Russian Federation in the Context of Macroeconomic Instability. International Journal of Energy Economics and Policy, 7(5), 28-33.

Tomaszewski, K. (2018). Polityka energetyczna Unii Europejskiej w kontekście problematyki bezpieczeństwa gospodarczego. Przegląd politologiczny, 1, 133-145.

Wasilewski, A. (2005). Aktualna sytuacja w sektorze gazu ziemnego Rosji. Nowoczesne Gazownictwo, 1, 44-50.

Zavalny, P. (2015). Challenges of the Russian gas industry. Retrieved from http://www. oilru.com/news/490672/

Zawadzki, S. (2018). Russia's Yamal LNG exports accelerate in time for winter, top Sakhalin. Retrieved from https://www.reuters.com/article/us-lng-russia/russiasyamal-lng-exports-accelerate-in-time-for-winter-top-sakhalin-idUSKCN1LG1BI

Neftyanaya otrast: itogi 2017 goda i kratkostrochnye perspektivy. (2017). Energeticheskiy byulleten, 56, 14-18. Retrieved from http://ac.gov.ru/files/publication/a/15796.pdf 